821.163.41.09

https://doi.org/10.18485/godisnjak.2018.13.2

Немања Ј. Радуловић*

Универзитет у Београду

Филолошки факултет
Оригинални научни рад

Примљен: 14. 09. 2018.

Прихваћен: 15. 10. 2018.

\title{
ИНДИЈА У МИСТИФИКАЦИЈАМА МИЛОЈЕВИЋА И ВЕРКОВИЋА
}

Од романтизма, заједно са новом дисциплином упоредне индоевропске лингвистике, јавља се и нова слика Индије везана за представу о сопственом пореклу. Она је утицала и на фолклористичке мистификације Милоша Милојевића и Стефана Верковића. Обојица користе представу саме земље као и имена из хиндуистичке митологије. Тиме су веровали да доказују старину Словена (код Верковића), односно Срба (код Милојевића).

Кључне речи: мистификација, фолклор, митологија, индологија.

Нова слика Индије, како се јавља са европским открићем санскрта и романтизмом, била је важна за формирање представа о земљи мудрости и поезије у књижевности и култури 19. века, али и за европску представу о сопственом пореклу. Библијску генеалогију Нојевих синова, из које су европски народи изводили своје порекло, заменила је индоевропска филологија која је понудила нови оквир: народи од Исланда до Бенгала припадају једној породици. У језичко проучавање уплело се и вредновање: сродност једног језика са санскртом била је потврда старине, а тиме и вредности. И након што се лингвистика одвојила од оваквих представа, оне су наставиле да живе у популарној имагинацији и аматерској науци.

"nem_radulovic@yahoo.com 
Таква слика Индије била је важна и за фолклористичке мистификације Милоша Милојевића и Стефана Верковића. Из више разлога њих двојицу треба помињати заједно. Обојица Гарашанинови агенти у пропаганди на простору „европске Турске”, обојица посвећени етнографији, пошли су од истих идеја и дошли до истих решења. Без обзира на све разлике међу њима (Милојевић је романтичарски фантастично представио српску прошлост а Верковић је на крају усвојио панбугарска становишта), треба их посматрати и по сличностима.

Милојевић је од 1869. до 1875. објавио три књиге народних песама и описа обичаја. ${ }^{1}$ Српско учено друштво је на основу негативне рецензије Стојана Новаковића и Милана Кујунџића (објављене 1873) одбило трећу збирку за штампу. ${ }^{2}$ Критика се тада одмакла од предромантичарског одушевљења, какво је било Хердерово Осијаном, ка филолошкој захтевности - случајеви Макферсона и Меримеа били су већ довољно познати, а у чешкој култури се водила расправа о Ханкиним рукописима. Милојевић је као романтичар већ у свом добу био анахрон (мада не и маргиналан: међу претплатницима прве књиге налазимо сва три кнежевска намесника). Народне песме и обичаји требало је да буду етнографски аргумент у доказивању „права народности”. Збирка је одбачена као неаутентична од већине фолклориста и коришћена само повремено и селективно, све док Владимир Бован није уложио труда у разликовање онога што би могло бити аутентично од оног што су Милојевићеве интервенције (Бован 1975). Оно што одмах упада у очи као траг прераде јесте уношење митолошких имена. Милојевић је записивао песме, али је изворна именовања замењивао именима словенских богова, од којих многи припадају свету кабинетске митологије. Божанства која Милојевић узима из застарелих теорија - Љељо, Пољељо, Лада - најбоље доказују његово ауторство. Заједно са словенскима, Милојевић је уносио и (псеудо)индијска имена и теме. Индија се јавља у два вида: кроз имена индијских богова и као помен саме земље.

Из хиндуистичке културе Милојевићеву пажњу највише је привукла замисао Тримурти, која обједињује Брахму, Вишнуа и Шиву. У хиндуизму, како се формирао након потискивања будизма па до данас, постоје три главне струје: вишнуизам (где се Вишну поштује кроз своје аватаре), шиваизам и тантризам (култ богиње). Без обзира на своје почасно место,

\footnotetext{
${ }^{1}$ Зачудо, у литератури се понекад наводи податак да је објавио две књиге песама.

${ }^{2}$ У описује као трећа.

З3ато и примећују да је код њега све другачије „од оног што се данас зна”: и географија и етнографија и етимологија. Ипак, критика је првенствено језичка, митолошке мистификације се и не помињу.
} 
Брахма нема своје следбенике. Тримурти је теолошки концепт који оваквим спајањем организује односе Брахме као створитеља, Вишнуа као одржаваоца и Шиве као уништитеља космоса. Ова представа привлачила је и раније пажњу хришћанских мисионара, као нека врста префигурације Свете Тројице; и пионир индологије Вилијем Џоунс осврнуо се на ту привидну сличност. Код Срба је Јован Илић правио паралеле и са словенском митологијом: „И Христова се вера није бог-зна колико разликовала од њихове [словенске, Н.Р.] вере пре Христа, на пр. бог Триглав био је у Срба, што у Инђијанаца 'Тримурта', у хришћана 'света Тројица'” (Илић б.г: 471).

Милојевић је имао неке основне информације о хиндуизму, па је представу Тримурти једноставно изједначио са митолошким Триглавом, познатим из средњовековних извештаја о балтичким Словенима, чије су три главе означавале власт над три нивоа света (Петрухин - Лома 2001: 538-539).

Милојевић поистовећује Тримурти и Триглава путем фантастичних етимологија. Нпр. песма бр. 9 прве књиге опева „Миле борце Триглав бора / триглав бора те Троице / Вишњег бога Створитеља / Јаког Живе рушитеља / и Брањања Бранитеља." Вишну је натегнуто повезано са епитетом „вишњи”, а Брањањ одговара Брахми; бор је, наравно, замена за „бог”. Другде је „Тригљав вељи” назван „Наш Створитељ и Држитељ / И велики Уморитељ” (I, 107), ${ }^{4}$ (в. и: I, 137, 138, 191, 200, 201; III, 13).

Још један митски лик је птица Гаруда или у деминутиву Гарудица (I, 139, 140; II, 31, 98 (б), 215). Гаруда је орао на ком лети громовник Индра, а код Милојевића се преображава у птицу лирске поезије, у љубави са птицом Гангелицом (од назива реке?).

Појављује се и Сива Жива (I, 107; III, 177; 198), другде (III, 193) Жива и Живана, као кћери Сиве и унуке Јаге (в. и: III, 317), поистовећена и са Светом Недељом (III, 424). Сива Жива путује у стару Индију и поклања се Триглаву (III, 429). У опису наводне игре вампира, девојка која преостане зове се „Жива негде Шива, негде Живана, негде Вила” (I, стр. 96). Изгледа да је ово име изведено од бога Шиве и повезано са псеудобожанством Живом. Шива се јавља и као варијанта женског имена Жива и као Жива рушитељ и као Сива ${ }^{5}$ и као отац Живе.

\footnotetext{
${ }^{4}$ Римска цифра означава број збирке, а арапска број песме, не број стране.

${ }^{5}$ Писање Сива (које се јавља и код других аутора тог периода) долази очигледно из западних извора где се име хиндуистичког бога транскрибовало француским с̧ (Данас се користи ś).
} 
Индија се помиње понекад као проклета (I, 104), јавља се као стара (III, 429) и света (III, 428), али је на првом месту српска земља: „У нас добро у Инђији. / У Инђији у Србији” (I, 199); „Во та Инђија Стара Србија / Стара Србија наша вочина” (I, 212). „Серберичани” су боравили у Индији „сто тисућ дугих љета / Двјеста тисућ кратких љета”, што је изгледа алузија на огромне космичке циклусе хиндуизма (дани и ноћи Брахме нпр.) Али, због греха и казне „Борич бора” морали су да је напусте: „Земље србске оставили/ И Инџију и Дунава" (I, 104). У другој Срби долазе из Индије у Рашку (I, 103). (Вид. и I, 105, 107, 188, 202, 247; II, 215; III, 204, 225).

Милојевић хиндуистичка божанства наводи заједно са словенскима и једноставно поистовећује индијски и словенски пантеон. Уместо реконструкције прамитологије и прајезика или тражења прапостојбине, за шта савремена индоевропеистика користи различите језике ове породице, он је Индију прогласио за прадомовину. Сем тога, овај хиндуизам, на чије се представе Милојевић позива, формирао се знатно након ведског, а поготово праиндоевропског периода, уз уношење прединдоевропских митолошких представа. Управо је Шива пореклом староседелачко божанство. У Ведама Вишну има споредно место, а Шива се под тим именом и не јавља.

И у својим историјским списима Милојевић је износио тезу да су Срби стигли из Индије. Песме треба да пруже доказ ове тезе. Индија је као колевка место легитимизације. Да би песма била митолошка, мора бити „индијска”, а то опет потврђује старину народа и даје му права у одређеном историјском тренутку.

Стефан Верковић, босански фрањевац који се на студијама теологије у Загребу упознао с илиризмом, у Србији је прешао на православље и ступио у службу владе. Био је заинтересован за материјалне остатке прошлости и нека врста раног археолога. Како говори у предговору првој књизи Веде Словена, водила га је жеља да пронађе доказе словенске старине, чиме се требало супротставити грчком осећају надмоћности над Словенима. Када их није нашао као писане трагове, био је сигуран да их може пронаћи у песмама. Оно за чим је трагао, Верковић је, на своје одушевљење, и пронашао. Наиме, поред мноштва песама и приповедака које је записао, а које се сматрају аутентичнима, учитељ Јован Попилијев Гологанов (Економов) донео му је из подручја Родопа песме које су говориле о пресељењу Словена из далеке прапостојбине на Дунав, о Орфеју, ${ }^{6}$ песме о жртвеном обреду или са именима божанстава. Ове песме је под насловом Веда Словена Верковић објавио у Београду 1874; други том изашао је у

${ }^{6}$ Верковић је веровао да постојање песама о Орфеју и Александру код словенског становништва доказује његову аутохтоност на Балкану. 
Санкт-Петербургу 1881. Његови историјски закључци изведени из песама (заправо одавно унапред постављени) јесу: а) да су Словени дошли из Индије; б) да су дошли пре Грка, тако да су идентични старобалканским народима попут Трачана. Појава песама одмах је отворила полемику у славистици која се може упоредити са расправом о Осијану из 18. века и чешком расправом о Ханкиним „открићима.” Један део проучавалаца био је уверен у аутентичност песама, рецимо Всеволод Милер, пионир ведских студија Емил Бирнуф, као и чешки слависта Леополд Гајтлер, једно време предавач санскрта на унверзитету у Загребу. С друге стране, Луј Леже одмах је препознао мистификацију, а каснији радови Ивана Шишманова и Михаила Арнаудова закључили су овај суд (преглед расправа: Беновска у ВC II 441-474; Бочков у ВC II 475-490). За питање се заинтересовао и Лаза Костић, ког је Веда Словена подстакла на идеју „живих палимпсеста"7. Данас се Веда Словена посматра као мистификација, коју је Верковићу, жељном старине, подметнуо његов сарадник с терена Гологанов. Веда се временом из опште славистике преместила у историју бугарске културе: како примећује Шишманов (7) то је била прва бугарска књига међународног значаја. Од осамдесетих година 20. века у бугарској хуманистици постоје тежње ка ревизионизму (преглед у: Христозова 56-69; за пример в. Богданов), али оне нису суштински оспориле тезу о осијанској генеалогији овог текста. Истраживања су премештала нагласке у детаљима: да ли је одговорност за мистификацију на Верковићу или Гологанову; да ли је основни извор једног или другог сарадника био Георги Раковски, ${ }^{8}$ или се Верковић још у Загребу могао упознати са идејама Шафарика и J. Грима, као и са далматинским „словинством” (Гундулић почетке словенске песме налази код Орфеја; уп. Тодоровски 12-16); да ли се и Милојевић инспирисао списима Раковског; какав је однос Верковићевих записа који су оцењени као аутентични према „родопским песмама.” Оно што је у

\footnotetext{
${ }^{7}$ За Костићеву инспирацију Верковићем в. детаљније у: Крњевић.

${ }^{8}$ Тим поводом треба поменути и да је Верковић у Цариграду упознао J. Хаџиконстантинова Џинота, другог заступника тезе о пореклу балканских Словена од старобалканских племена, с којим је изгледа имао сарадњу и касније (Џамбазовски 1960: 26, 61). Изгледа да мрежа Верковићевих контаката може пружити још материјала за истраживање. Рецимо, уз његову рукописну збирку народних песама која се чува као део етнографске збирке Архива САНУ (бр. 282) стоји напомена: „Ову збирку предала је Академији на откуп породица пок. Симе Лукина Лазића, књижевника из Новог Сада, те је у старом инвентару она заведена под његовим именом, само је накнадно плавом оловком додато име Верковићево. - Ове песме не налазе се у збиркама које је Верковић штампао у Београду 1860 и 1874...” Питање атрибуције збирке на страну, веза два имена је интересантна јер је и Лукин Лазић био пропагатор романтичарских параисторијских теза. Саме песме иначе нису мистификаторско-митолошког карактера, већ делују као варијанте уобичајених сижеа народне епике.
} 
новијим истраживањима значајније од разматрања питања аутентичности, односно контекста Верковићевог рада, јесте улога Веде у култури 19. века као и тема саме Веде као текстуалне целине, као књиге. У сваком случају, јасно је да је слика Индије имала велику улогу у формирању ове мистификације. По томе се Верковић разликује од ранијих хуманистичких изједначавања античких становника Балкана са Словенима (нпр. Винко Прибојевић): романтизам је као преокрет увео Индију и лингвистички аргумент.

(Да ли Верковић припада српској књижевности? Не отварам ово питање због пуке класификације, већ оно илуструје особено схватање идентитета. Његово мењање средина подсећа на једног Григорија Цамблака; али док се Цамблак кретао на подручју Slaviae orthodoxae, Bepковићева Славија изгубила је верски предзнак. Он се изјашњава и као Хрват (у писму Старчевићу: Арнаудов 40) и као Србо-Хрват (у предговору првој књизи Веде) и као „Словен Хрвато-Србин то јест Илир” (у писму Бирнуфу - Доклестић Стјепан Верковић 128), панслависта је и русофил, присталица самодржавља. Улогу у свему томе је свакако имало и питање практичног позиционирања између две средине и две владе, српске и бугарске (,„лавирање”, како каже Арнаудов 96). ${ }^{9}$ У самопредстављању је пак своје „словенство” поставио насупрот Хеленима и Западњацима).

Давањем амбициозног наслова Верковић је хтео да своју књигу представи као сведочанство словенске цивилизације древности, упоредиву са светом књигом Индијаца, али и да је непосредно повеже са ведском религијом. Као и код Милојевића, Индија је требало да пружи легитимитет старини а она је доказана присуством имена индијских божанстава. То су Вишну (писан и Вишњу), Огнен бог (Игне бог) и Сива (I, 5, 11, 13, 14, 15; II, стр. $25,28,61,798) .{ }^{10}$ Први је очигледно, како су приметили већ рани критичари, погрешно доведен у везу са придевом вишњи, односно придев је прочитан како се хтело (и у упоредном француском преводу у првом тому - Vishnou). Овај се придев често јавља и код Милојевића. Огнен треба да одговара Агнију, а Сива Шиви. У једној песми (II, 97), Сива има три змије на глави, што донекле подсећа на иконографску представу Шиве, са змијом око врата (цео контекст песме је календарско-обредни, далек од индијског миљеа). На једном месту (II, 225) јавља се Дурга (санскрт-

\footnotetext{
${ }^{9}$ Само делимично успешно. У српским радовима тог доба о Македонији Верковић је изашао на лош глас (нпр. Иванић 23; Протић 27-28; Гопчевић 242-243; 265-266). Међутим, фалсификовање песама које аутори помињу не односи се на митолошка кривотворења већ на Верковићево представљање грађе као бугарске.

${ }^{10}$ Код првог тома, арапске цифре означавају број песме; код другог број стране, пошто нумерација песама у другој књизи Веде није континуирана.
} 
ско име главне хиндуистичке богиње, поштоване и под многим другим именима) као небеска богиња. Помињу се и натприродна бића „два Дефа” $(\mathrm{I}, 11)$, изгледа везана за индијске деве (богови); на ово упућује упоредни француски превод Dèves, у мн; али са Deve преводи се и реч „Дефка”.

Верковић-Гологанов текстуализују словенску религију. Они уводе постојање књига у старини као знак древне културе. У објашњењима се помиње више различитих обредних књига, од којих Јасна подсећа на авестијску (II, 390). У неколико песама јавља се „Вета књига” (II, 394, 439, 458). Објашњена је (II, 577) као књига која је садржала песме за курбане, јасно према Ведама као збиркама жртвених напева. У једној песми из архива говори се о пореклу књиге Веде, златне књиге (BC II, 426-430). Верковићеви Словени приносе жртву (означену ипак народним муслиманским изразом курбан) од птица или од три или девет крава. (Што се Индије тиче, у ведском периоду крава је била жртвена животиња, али је временом њено убиство постало тежак грех, каквим се и данас сматра; хиндуизам је напустио ведски обред животињског жртвовања). Гологанов је обећавао и дугачке песме о рођењу „Вишну бога” и о „Триници” (Вишну, Коледа и Сурва) тј. Тримурти.

Милојевић, Верковић, други романтичарски аутори и њихови наследници посебно су склони фантастичним етимологијама као средству доказивања. Вредно је пажње да најутицајнији проучавалац митологије тог периода, Макс Милер, заступа тезу да митови настају као „болест језика", истим процесом као и народне етимологије. На страну колико је Милерова потіna пuтina формула заиста објашњење за настанак митова архајског доба, етимологисање је очигледно утицало на митопоетске процесе савремених мистификатора. Не мора бити реч о непосредном Милеровом утицају (мада је Верковић за њега знао), већ се може радити и о спонтаним процесима.

Верковић-Гологанов се понегде ставља заједно са Макферсоном, чак и Блејком (Тодоровски 24, Богданов), а негде се овакво поређење естетски сматра промашеним (Шишманов). Несумњиво је реч о појавама које припадају истом току осијанског наслеђа, мада су остварења различите и поетске и митске ширине. На страну естетско вредновање, какав је заправо тај псеудоиндијски свет Веде?

И Верковић и Милојевић желе да створе слику древне митологије, да попуне лакуне које постоје у познавању религије Словена, а за то узимају из Индије, боље рећи „Индије”, једне површне и хаотичне визије коју су имали о овој култури. Оно што је значајније јесте да нас и поред њихове тежње, ови текстови не премештају у другачији, митолошки свет. Митско, 
индијско и древно треба да послужи савременом схватању националности. У том смислу је код њих мит подређен историји (чак и непосредном политичком циљу). ${ }^{11}$ Они нуде „митске” текстове који треба да докажу пресељење Словена, Срба, чиме се уноси суштински еухемеристички кључ схватања мита. Тако је и њихова Индија није далека, егзотична земља, већ постаје „наша”, а старина треба да сведочи о данашњим правима. Ово се јасније може видети код Милојевића. Код Верковића је фасцинација старином имала и дубљу идеолошку подлогу. Обузет својеврсним месијанством, он је у свом сакупљачком раду видео ништа мање него мисију против идеја Ренана и Дарвина (Тодоровски 95).

Изгледало је да су ове збирке отишле на маргине проучавања. Међутим, доживеле су у новије време неочекиван revival. Већ смо поменули оживљено занимање за Верковића у Бугарској почетком осамдесетих. Шири друштвени контекст открива и могућу политичку мотивацију (прослава 1300 година бугарског царства, као и државно улагање у тракологију, на иницијативу утицајне Људмиле Живкове). Код нас су следбеници тзв. аутохтонистичке школе. тј. неоромантичарске параисторије, подсетили на Милојевића као на једног од пионира (потиснутог из „званичне науке”, према њима). Наслов једне од таквих публикација, Обредне пјесме древних Срба из Индије, довољно је илустративан за ову тему. Верковићова Веда недавно је преведена на руски а водећи савремени мистификатор, Александар Асов, користио се њом и пре. Савремени родноверни, као и аутори 19. века, често поистовећују „ведску” религију са „словенском”, па се неки облици неопаганизма називају и „словенски ведизам”. Још је Мирољубов изједначио словенско паганство са ведском религијом, па тако и Велесова къига користи индијске термине (Радуловић 282). Ово дело настало половином 20. века припада истој жанровској традицији као и списи Милојевића и Верковића, а у којој, како видимо, индофилија има значајно место.

${ }^{11}$ Према једном схватању Веда Словена може се посматрати и као календарски циклус и као народна хроника, разумљива у контексту неофицијелне апокрифне културе (Христозова 198). Уместо предмодерних хроничарских облика, чини ми се да су значајнији управо модерни утицаји: индоевропска лингвистика, словенофилство и култ фолклора. 


\section{ИЗВОРИ}

Арсеновић 2008: А. Б. Арсеновић, Обредне пјесме древних Срба из Индије, Београд: Мирослав.

Верковић 1874: С. Верковић, Веда Словена. Български народни песни I Београдъ.

Веда Словенахъ II С.-Петербург, 1881.

ВС Веда Словена 1-2. София: Отворено общество, 1997.

Верковић: С. Верковић, Српске народне песме из Сереза, Етнографска збирка бр. 282 Архива САНУ.

Гопчевић 2008: С. Гопчевић, Стара Србија и Македонија, Београд: Народна библиотека; Приштина: Универзитетска библиотека „Иво Андрић” (репринт издања из 1890).

Иванић 1906: И. Иванић, Маћедонија и Маћедоничи, Београд: Штампа Савића и комп.

Илић: Ј. Илић, Целокупна дела, Београд, б.г.

Милојевић 1869: М. Милојевић, Песме и обичаи укупног народа србског. Књига прва, Обредне песме. Београд: Државна штампарија.

Милојевић 1870: М. Милојевић, Песме и обичаи укупног народа српског. II к. Сватовске. Београд: Државна печатница.

Милојевић 1875: М. Милојевић, Песме и обичаји укупног народа српског. III књига. Београд: Државна штампарија.

Милојевић 2015: М. Милојевић, Одломци историје Срба и српских-југословенских-земаљь у Турској и Аустрији, Београд: Феникс либрис и др,

Протић 1928: С. М. Протић, О Македонији и Македонщима, Београд: Скрелић, (прво издање 1888).

\section{ЛИТЕРАТУРА}

Арнаудов 1968: М. Арнаудов, Веркович и 'Веда Словена', София: Българска академия на науките.

Беновска 1997: М. Беновска, „Хроника на спора за Веда Словена”, у: Веда Словена. София: Отворено общество, 441-474.

Бован 1975: В. Бован, Косовско-метохијске народне песме у збирии М. С. Милојевића. Приштина: Јединство.

Богданов 1991: И. Богданов, 'Веда Словена' и нашето време, София: Университетско издателство „Св. Климент Охридски”.

Бочков 1997: П. Бочков, „Хроника на спора за Веда Словена - мистификация или мистифицирана", у: Веда Словена, София: Отворено общество, 475-490. 
Доклестић 1981: Lj. Doklestić, „Životni put Stjepana Verkovića (18211894)", u: Radovi Zavoda za hrvatsku povijest Filozofskoga fakulteta Sveučilišta u Zagrebu 14.1, 229-358.

Доклестић 2007: Lj. Doklestić, Stjepan Verković. Život i djelo (18211894), Zagreb: Srednja Europa.

Петрухин, Лома 2001: В. Ј. Петрухин, А. Лома, „Триглав”, у: Словенска митологија, Београд: Zepter Book World, 538-539.

Радуловић 2018: Н. Радуловић, „Нов живот Велесове књиге: преображај мистификације у свету књигу”, у: Српска славистика 2. Књижевност, култура, фолклор. Радови српске делегащије на XVI међународном конгресу слависта, Београд: Савез славистичких друштава Србије, 277-284.

Тодоровски 1967: Г. Тодоровски, „За и против Веда Словена”, у: Годишен зборник на Филозофскиот факултет на Универзитетот во Скопје, 19 (1967), 394-444.

Тодоровски 1965: Г. Тодоровски, Веда Словена и нејзините мистификатори, Скопје, 1965; (докторска теза; машинопис-примерак Универзитетске библиотеке „Светозар Марковић” у Београду).

Христозова 2012: М. Христозова, 'Veda Slovena'zwischen Mythos und Geschichte, München: O. Sagner.

Џамбазовски 1960: К. Џамбазовски, Културно-општествените врски на Македонщите со Србија во текот на XIX в, Скопје: Институт за национална историја.

Шишманов 1997: И. Шишманов, „Френската наука и Веда Словена”, у: Веда Словена II, София: Отворено общество, 7-42.

Nemanja J. Radulović

\section{INDIA IN MYSTIFICATIONS OF MILOŠ MILOJEVIĆ AND STEFAN VERKOVIĆ}

\section{Summary}

With Romanticism and with a new field of comparative Indo-European linguistics, a new image of India emerged in European culture. It changed the way how Europeans saw their own origins. This kind of influence can be discerned in folkloric mystifications by Miloš Milojević and Stefan Vekrović in 19th century. Both use names from Hinduism and create the image of India as the ancient homeland for "proving" the antiquity of Slavic nations (Verković), or Serbs more specifically (Milojević).

Keywords: mystification, folklore, mythology, Indology 